\title{
JUURNAL_RU
}

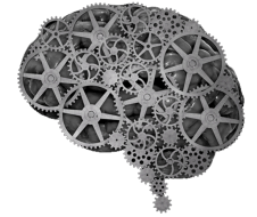

COMPANY GROUP "INTELLEKT"

\author{
Стагниева И.В., Гукасян Е.Л. \\ Ростовский государственный медицинский университет \\ Ростов-на-Дону, Россия
}

doi: 10.18411/lj2016-3-35

\section{Способ диагностики тяжести течения риносинусита}

Риносинусит - воспаление слизистой оболочки полости носа и околоносовых пазух. Различают три степени тяжести риносинусита: легкую, среднюю и тяжелую степени. Определение степени тяжести риносинусита строится, как правило, на основании клинической картины заболевания, основываясь в значительном количестве случаев на субъективных симптомах заболевания, что приводит к недостаточной эффективности определения степени тяжести риносинусита[1]. Целью исследования стала разработка объективного способа определения степени тяжести риносинусита. Тяжесть риносинусита зависит от степени выраженности воспалительной реакции. IL-1 $\beta$ - многофункциональный цитокин с широким спектром действия, инициирует и регулирует воспалительные, иммунные процессы, активирует нейтрофилы, Т- и В-лимфоциты, стимулирует синтез белков острой фазы и др. цитокинов. Антагонистом IL $-1 \beta$ является IL-10, который подавляет секрецию активированными моноцитами IL $-1 \beta$. IL-10 является противовоспалительным цитокином. Поэтому именно IL $-1 \beta$ и IL-10 были взяты для определения степени тяжести риносинусита $[2,3]$.

Материалы и методы. Нами было обследовано 120 больных риносинуситом, находившихся на лечении в оториноларингологическом отделении МБУЗ «Городская больница №1 им. Н.А. Семашко г. Ростова-на- 
Дону». Всем больным было выполнено полное клинико-лабораторное обследование. Оценка степени тяжести риносинусита определялась по ВАШ и по клиническим признакам заболевания, таким как отсутствие или повышение температуры тела, заложенность носа, выделения из носа, головная боль в проекции околоносовых пазух [4]. Контрольную группу составили 30 здоровых людей в возрасте 20-55 лет.

У больных всех групп и группы контроля уровень цитокинов IL-1 $\beta$ и IL-10 определяли методом иммуноферментного анализа. По тяжести риносинусита больные были разделены на 3 группы: 1 группа - пациенты с легкой степенью тяжести (43 пациента); 2 группа - пациенты со средней степенью тяжести (38 пациентов); 3 группа - с тяжелым риносинуситом (39 пациентов). В 1-й группе пациентов было отмечено превалирующее повышение уровня противовоспалительного цитокина IL-10, по сравнению со всеми группами сравнения: 2-й, 3-й и контрольной $(\mathrm{p}<0,01)$. Уровень провоспалительного цитокина IL-1 $\beta$ был значительно ниже, чем во 2-й и 3 -й группах $(p<0,01)$, но достоверно не отличался от контрольной группы (p>0,1). При этом системная воспалительная реакция, определенная согласно проведенному обследованию, была выражена слабо, что клинически соответствовало легкой степени тяжести. Во 2-й группе больных уровни обоих цитокинов были повышены по сравнению со всеми группами сравнения: 2-й, 3-й и контрольной $(p<0,01)$. Воспалительная реакция, определенная согласно проведенному обследованию клинически соответствовала средней степени тяжести риносинусита. В 3-й группе больных было отмечено превалирующее повышение уровня провоспалительного цитокина IL-1 $\beta$ ( $<0,001)$. Уровень противовоспалительного цитокина IL-10 был резко снижен по сравнению со 2 -й и 3 -й группами $(\mathrm{p}<0,001)$, но достоверно не отличался от контрольной группы (p>0,5), что подтверждало активность воспаления.

Абсолютные значения уровней цитокинов в исследуемых группах имели значительный разброс, тогда как преобладание про- или 
противовоспалительного звена имело четкую направленность $[5,6,6]$. Соотношение уровней цитокинов, а не их абсолютные значения, наиболее полно отражают направленность иммунной реакции и активность воспаления и могут быть использованы в качестве критериев определения степени тяжести воспаления при риносинусите. В 1-й группе больных величина соотношения IL1ß/IL-10 составила менее 1,3 , что соответствовало легкому течению риносинусита; во 2-й группе больных величина соотношения IL-1ß/IL-10 составила от 1,3 до 5,5, включительно, что соответствовало средней степени тяжести течения риносинусита; в 3-й группе величина соотношения IL-1ß/IL-10 составила более 5,5 , что соответствовало тяжелому риносинуситу.

Таким образом, предложенный способ позволит повысить эффективность определения степени тяжести риносинусита за счет использования объективных критериев оценки, позволяющих четко, быстро и однозначно определять степень тяжести заболевания. 


\section{Литература:}

1. Fokkens W.J., Lund V. J., Mullol J. et al. European position paper on rhinosinusitis and nasal polyps-EPOS 2012 // Rhinology. - 2012. - № 50 (1). P. 1-12).

2. Стагниева И.В., Гукасян Е.Л., Сагакянц А.Б. Нарушение нейроиммунной реактивности у больных рино $с$ синуситом//Российская ринология. 2015.T. 23. - № 1. - C. 25-28.

3. Бойко Н.В., Писаренко Е.А., Морозова Е.Е., Вербицкая Л.П., Колесников В.Н. Диагностика и лечение одонтогенного синусита // Российская ринология. - 2009. -№3. - С.6-10.

4. Принципы этиопатогенетической терапии острых синуситов: методические рекомендации /Абдулкеримов Х.Т. и соавт.; под ред. Рязанцева С.В. - СПб.: Полифорум Групп, 2014. - с. 5.

5. Стагниева И.В., Симбирцев А.С. Определение роли субстанции р и болевого симптома в диагностике иммунных нарушений при риносинусите // Иммунология. - 2015. - Т. 36. - № 5. - С. 295-300.

6. Бойко Н.В., Панченко С.Н., Кириченко Ю.Г. К вопросу о морфогенезе инвертированной папилломы носа // Российская ринология. - 2008. - Т.16. - №3. - C. 23-28.

7. Стагниева И.В., Симбирцев А.С. Эффективность иммуномодулирующей терапии у больных риносинуситом // Медицинская иммунология. 2015. -. 17. № 5. - C. 423-430. 